\title{
ADB'S RAPID COVID-19 RESPONSE IN SOUTHEAST ASIA
}

The coronavirus disease (COVID-19) has had devastating impacts in Southeast Asia. The Asian Development Bank (ADB) quickly responded with a substantial assistance package, and continues to work on additional support to help countries address the impacts of the pandemic.

ADB's support has been focused on three crucial areas: (i) supporting healthcare responses to save lives; (ii) supporting the poorest and most vulnerable suffering dire economic hardship; and (iii) addressing the devastating impacts of COVID-19 on businesses and economies to help countries rebound after the crisis.

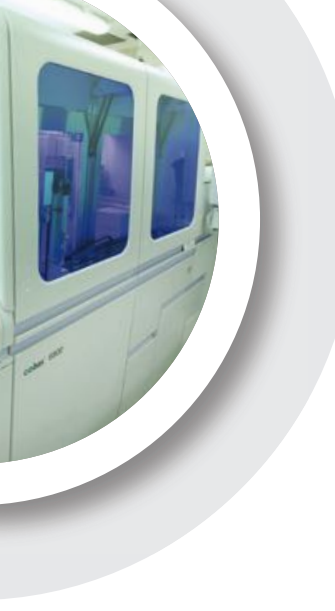

As of April 2021
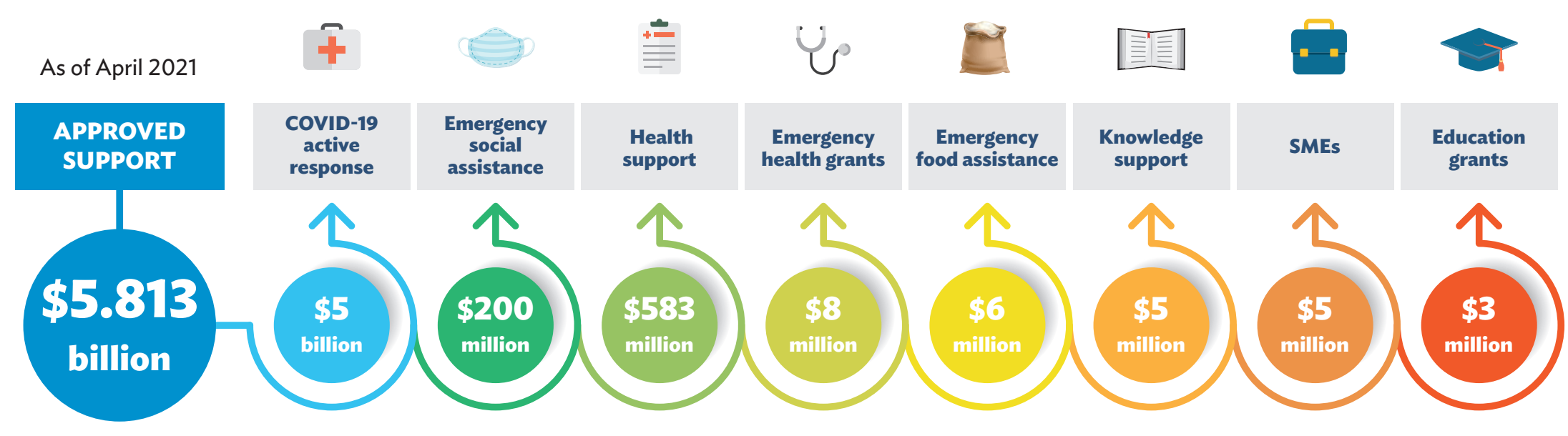


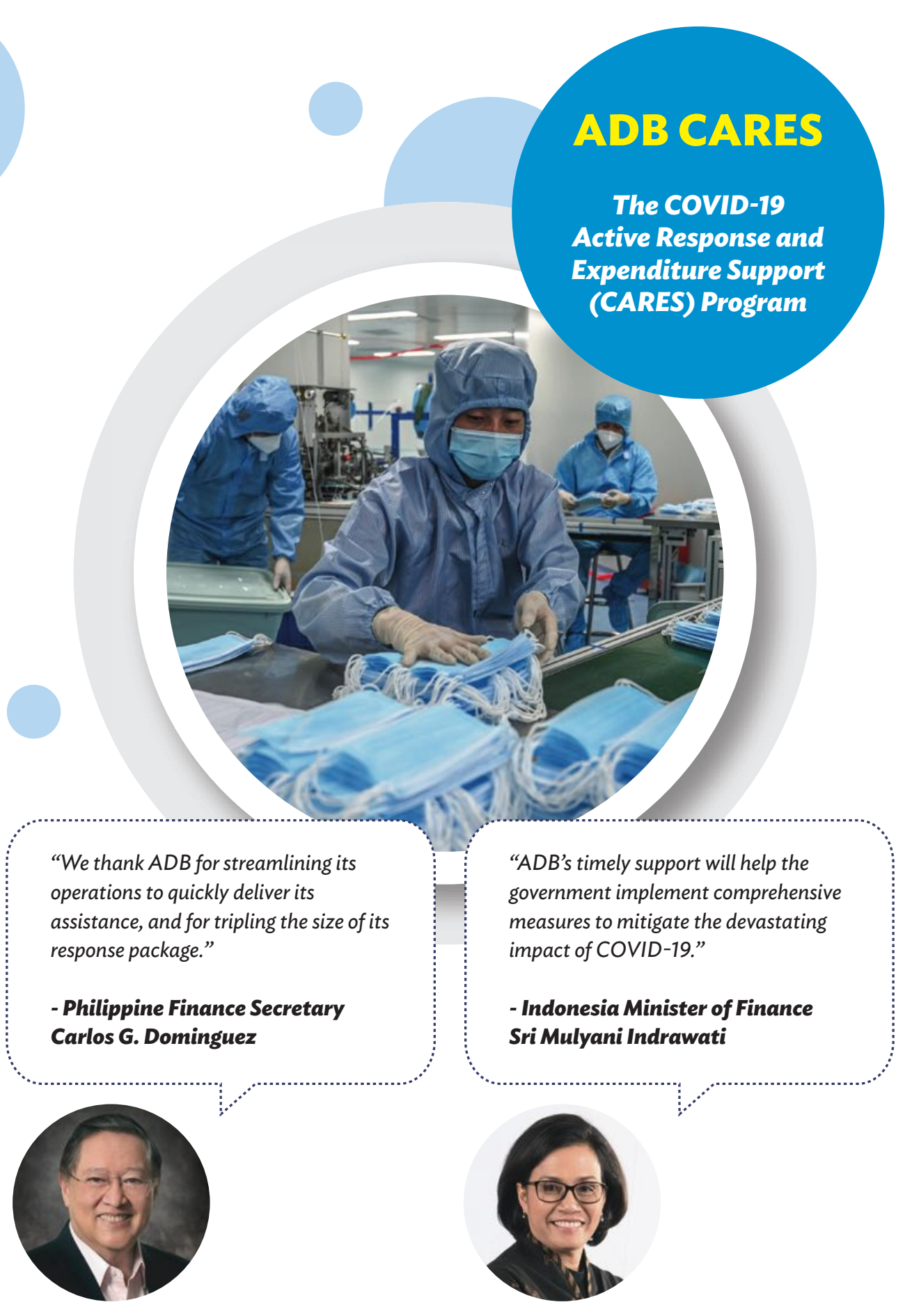

CAMBODIA
\$250 million to support government efforts to
strengthen the country's healthcare system,
increase social assistance to the poor and vulnerable,
and provide economic stimulus to businesses, including
small and medium enterprises.
INDONESIA
\$1.5 billion to support the government in expanding
social assistance programs, boosting resources for
COVID-19 prevention and control, and safeguarding
workers and productive sectors from the economic
downturn.


VACCINES FOR

THE PHLIPPINES

AND INDONESIA

O

O

$\bigcirc$

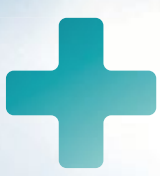

Under ADB's Asia Pacific Vaccine Access Facility (APVAX),

ADB has provided support to Indonesia and the Philippines

to support the countries' procurement and distribution of COVID-19 vaccines.

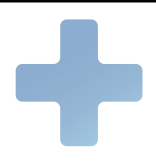

\section{PHILIPPINES}

The Philippines was the first recipient of financing support under APVAX. On 12 March 2021 ADB approved a $\$ 400$ million loan under the second that will help the Department of Health procure and deliver safe and effective vaccines against COVID-19. ADB's joint support with Asian Infrastructure Investment Bank (AIIB) will together fund the procurement of up to 110 million doses of COVID-19 vaccines for as many as 50 million Filipinos. This assistance builds on earlier \$25 million in ADB support in January 2021 to fund the government's advance payments to vaccine suppliers to secure the delivery of vaccines.

$A D B$ is also providing technical advisory assistance to the government on vaccine procurement and its national vaccine road map. ADB technical support also includes assistance to help the government implement and monitor its vaccine prioritization plan, medical waste management program, and vaccine information management system.

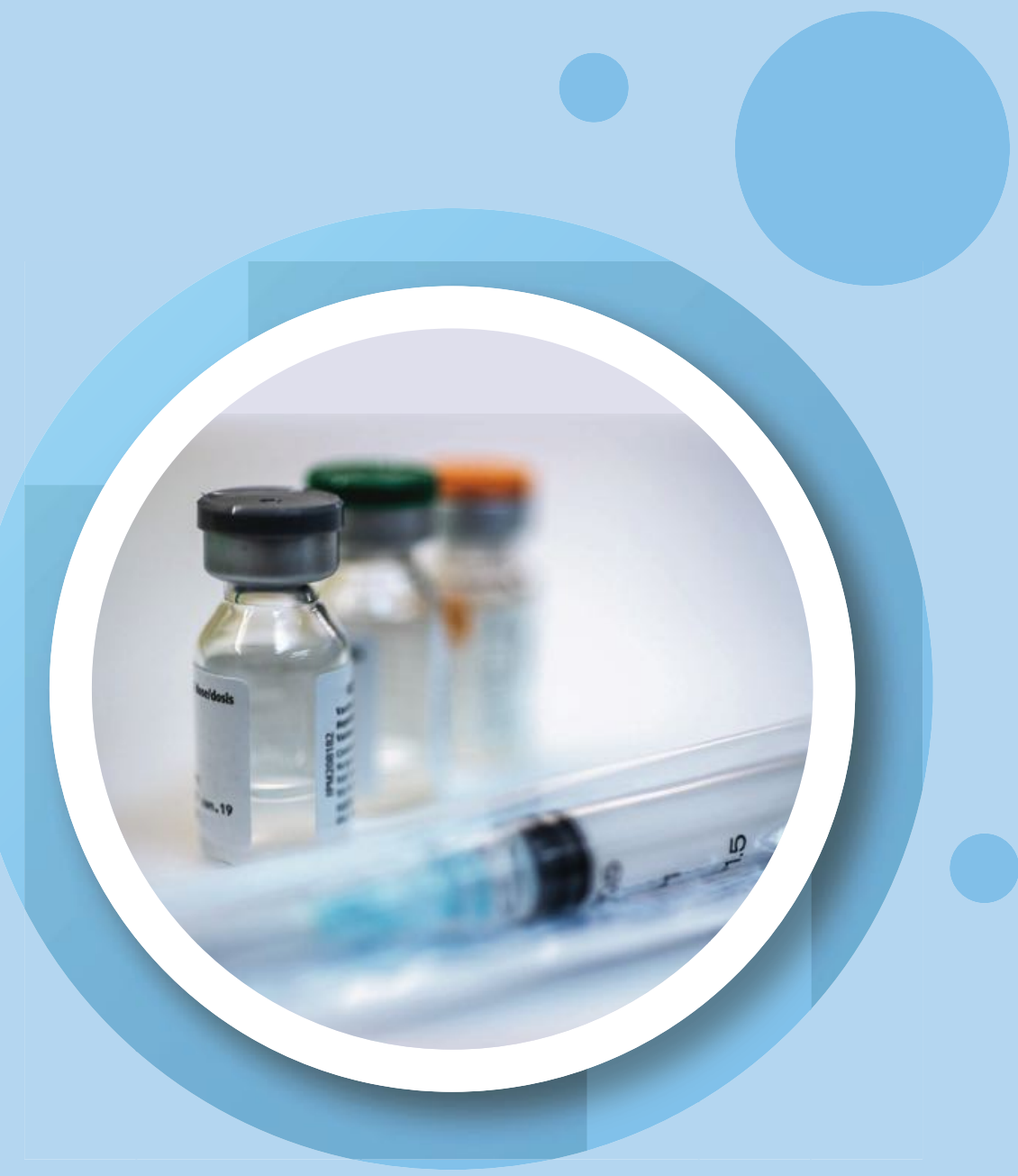

\section{INDONESIA}

On 31 March 2021 ADB approved a \$450 million loan to Indonesia to help Bio Farma, a state-owned vaccine supplier, procure and deliver safe and effective vaccines against COVID-19. The Responsive COVID-19 Vaccines for Recovery (RECOVER) project will fund the purchase of at least 65 million doses of COVID-19 vaccine for priority groups. The project is supported by APVAX.

In tandem with this support, ADB will also help the government and Bio Farma improve logistics management and deliver vaccines more effectively. 
ADB quickly reprogrammed funds under the Greater Mekong

Subregion (GMS) Health Security Project for rapid delivery of

essential medical equipment.

ADB also topped up current

assistance with a $\$ 2$ million grant

to strengthen GMS countries'

capacity for epidemic response,

provide laboratory equipment,

and enhance regional cooperation

on disease surveillance.
ADB approved a $\$ 3$ million grant financed by APDRF to provide emergency medical supplies and equipment, including test kits and ventilators, to strengthen medical care delivery in Indonesia.
COVID-19 test equipment was quickly procured and delivered to the Philippines. The new laboratory at the Jose B. Lingad Memorial

Regional Hospital in

Pampanga was fully functional by mid-May, nearly doubling the country's current testing capacity by processing at least 3,000 tests a day.
ADB approved $\$ 200$ million in additional finance for the Philippines that will support the government's work to quickly provide COVID-19 emergency unconditional cash grants to vulnerable households who are beneficiaries of the Pantawid Pamilyang Pilipino Program (4Ps), to help them persevere during the enhanced community quarantine.
ADB approved a $\$ 1$ million grant to Timor-Leste, financed by APDRF, to support the government's COVID-19 response, including providing urgent food assistance to vulnerable households.

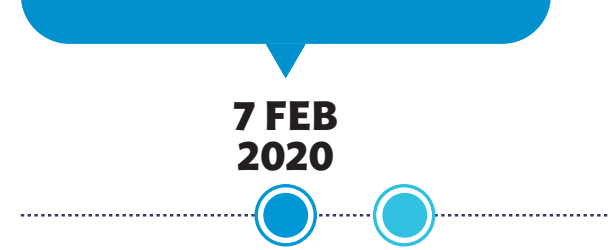

13 MAR 2020

ADB approved a $\$ 3$ million grant financed by the Asia Pacific Disaster Response Fund (APDRF) for lab equipment and personal protective equipment (PPE) in the Philippines.

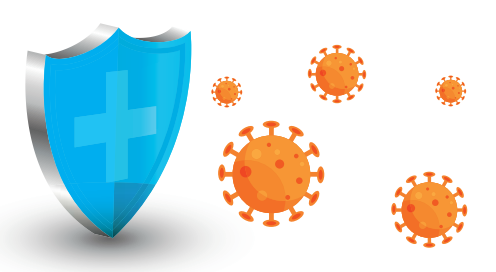

\section{MAR} 2020
22 APR

2020
27 APR 2020
22 JUN 2020

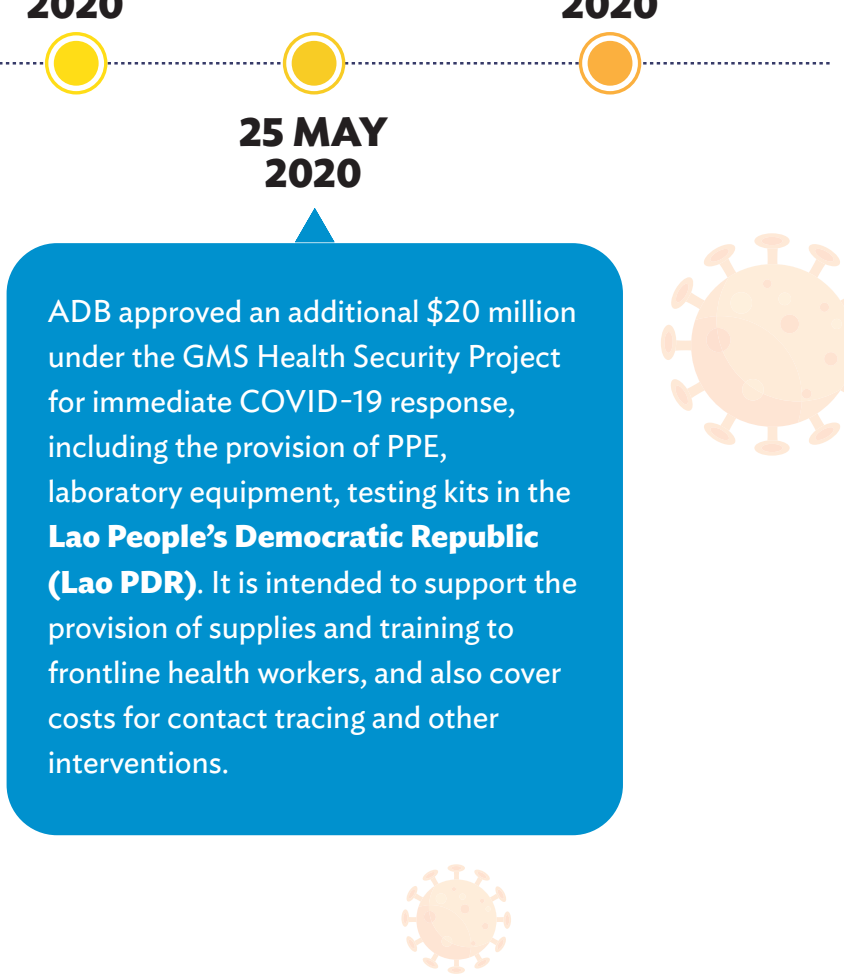

ADB launched a $\$ 5$ million grant for the Philippines and mobilized P28 million (approximately $\$ 557,000$ ) in voluntary contributions from the private sector and the ADB staff community. This helped the government deliver critical food supplies to 162,000 vulnerable households in Metro Manila, which were under enhanced community quarantine to contain the spread of COVID-19.
ADB swiftly approved

\section{APR} 2020

$\$ 3$ billion under the COVID-19 Active Response and

Expenditure Support (CARES) Program, ADB's countercyclical support facility to Indonesia and the Philippines to mitigate COVID-19's impact on public health, livelihoods, and economies, and to help guide countries' transition from pandemic management to economic recovery. 
ADB approved $\$ 250$ million to Cambodia under the CARES Program to support the government's work to address COVID-19 social, health, and economic impacts.
ADB approved the $\$ 125$ million Health System Enhancement to Address and Limit (HEAL) COVID-19 Project, which will help the Philippines improve health services across the country through the provision of critical medical equipment and related training, including support for the government's scale-up of

COVID-19 tests, surveillance, and infection prevention and control.
ADB approved a $\$ 2$ million Japan Fund for Poverty Reduction (JFPR) technical assistance (TA) for the Philippines to support last-mile school learners in disadvantaged and remote communities to continue learning through education technology during the COVID-19 pandemic. An additional $\$ 1.2$ million TA will provide solar-powered transistor radios to 55,000 last-mile learners in areas without reliable electricity or internet connectivity.

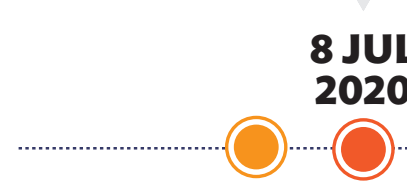

26 JUN 2020

ADB approved $\$ 1.5$ billion under the CARES Program to support Thailand in its work to mitigate COVID-19's health and livelihood impacts, and to support economic recovery efforts.

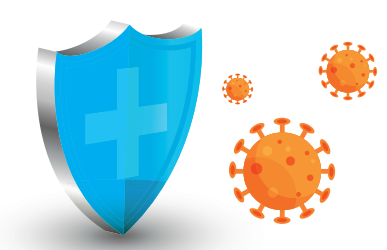

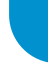

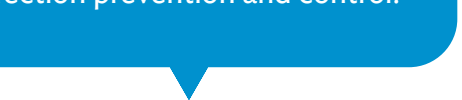

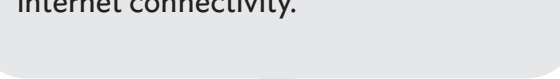

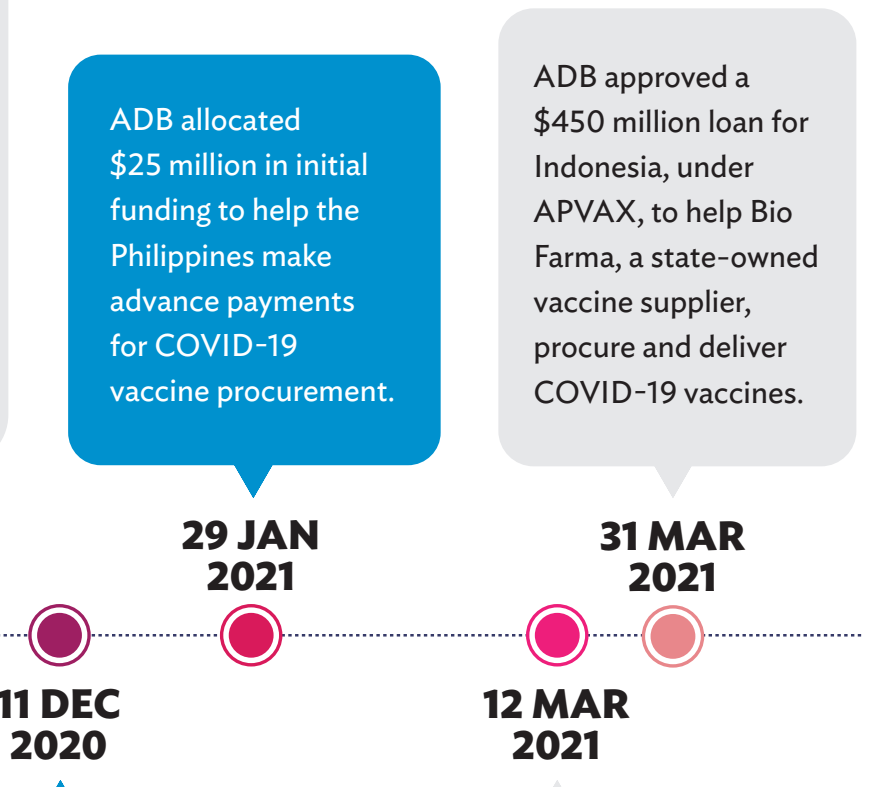

ADB approved $\$ 250$ million under the CARES Program to support Myanmar's COVID-19 response

through support for social assistance, health care, and economic recovery.
25 AUG ....

21 AUG 2020

9 OCT 2020
11 DEC 2020

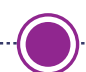

ADB approved a $\$ 30$ million loan under the GMS Health Security Project to boost Myanmar's COVID-19 response through the provision of improved clinical care and management, and infection prevention control, particularly in areas with a high minority population but inadequate health care access.
ADB approved a

$\$ 400$ million loan for the Philippines, under APVAX, to help the country purchase COVID-19 vaccines. 


\section{FOOD FOR MANILA'S POOREST}

In the Philippines, quarantine measures saved lives, but also created economic hardship for families. Manila is ADB's home. Staff felt that particularly the poorest and most vulnerable households need emergency support. ADB took fast action, approving within one week an innovative $\$ 5$ million grant that delivered food to 162,000 households in Metro Manila, in partnership with the government and private sector. The program fed at least 800,000 people, and was completed in little more than one month. It is hoped this program can establish a template that can be replicated in other Asian countries confronting similar issues.

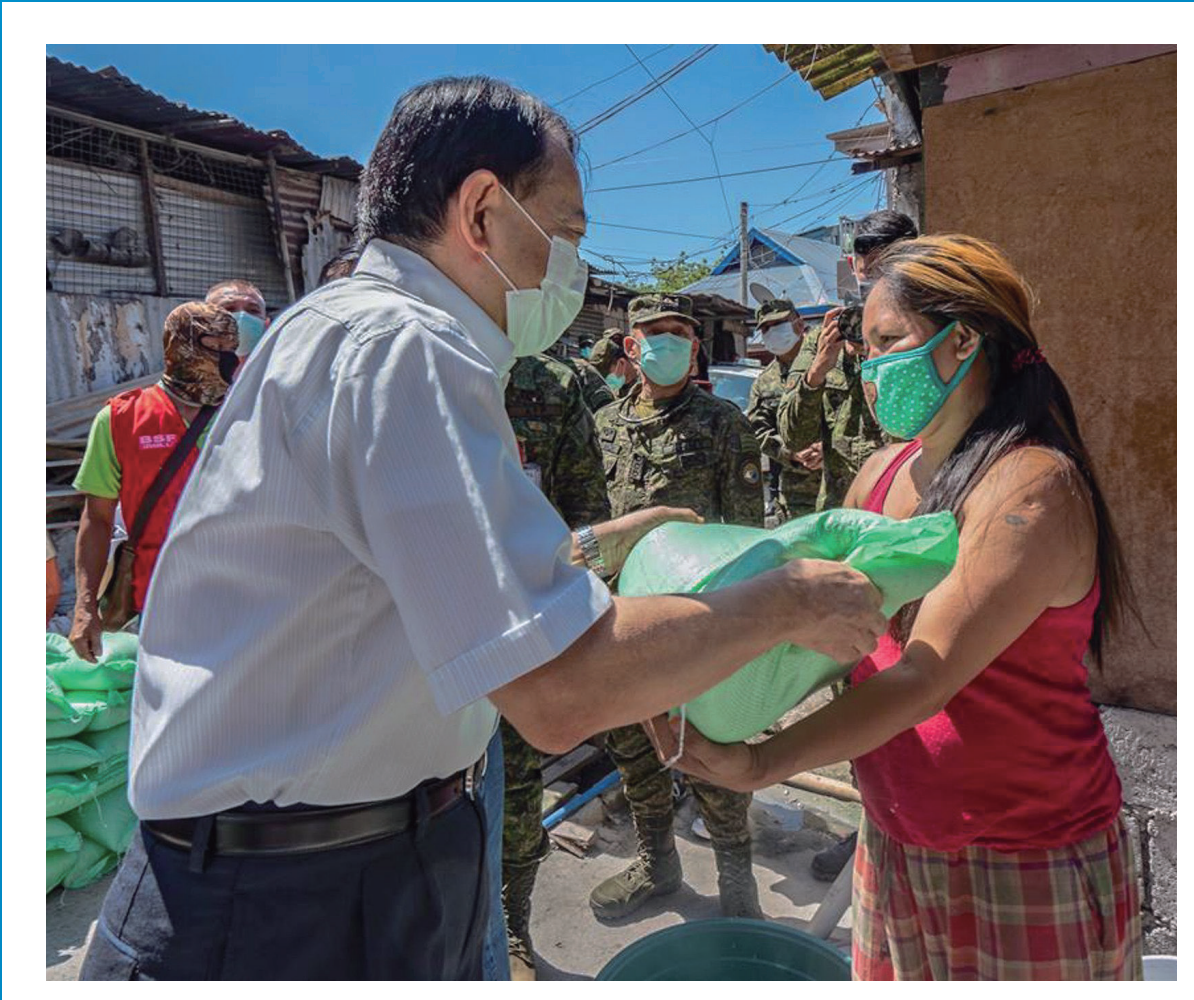

\section{GREATER MEKONG SUBREGION}

ADB has reprogrammed over $\$ 8$ million under the Greater Mekong Subregion (GMS) Health Security project to support a range of COVID-19 response measures, including the rapid delivery of essential medical equipment that health providers need to stay safe and save lives, as well as capacity building for infectious disease outbreak prevention and response:

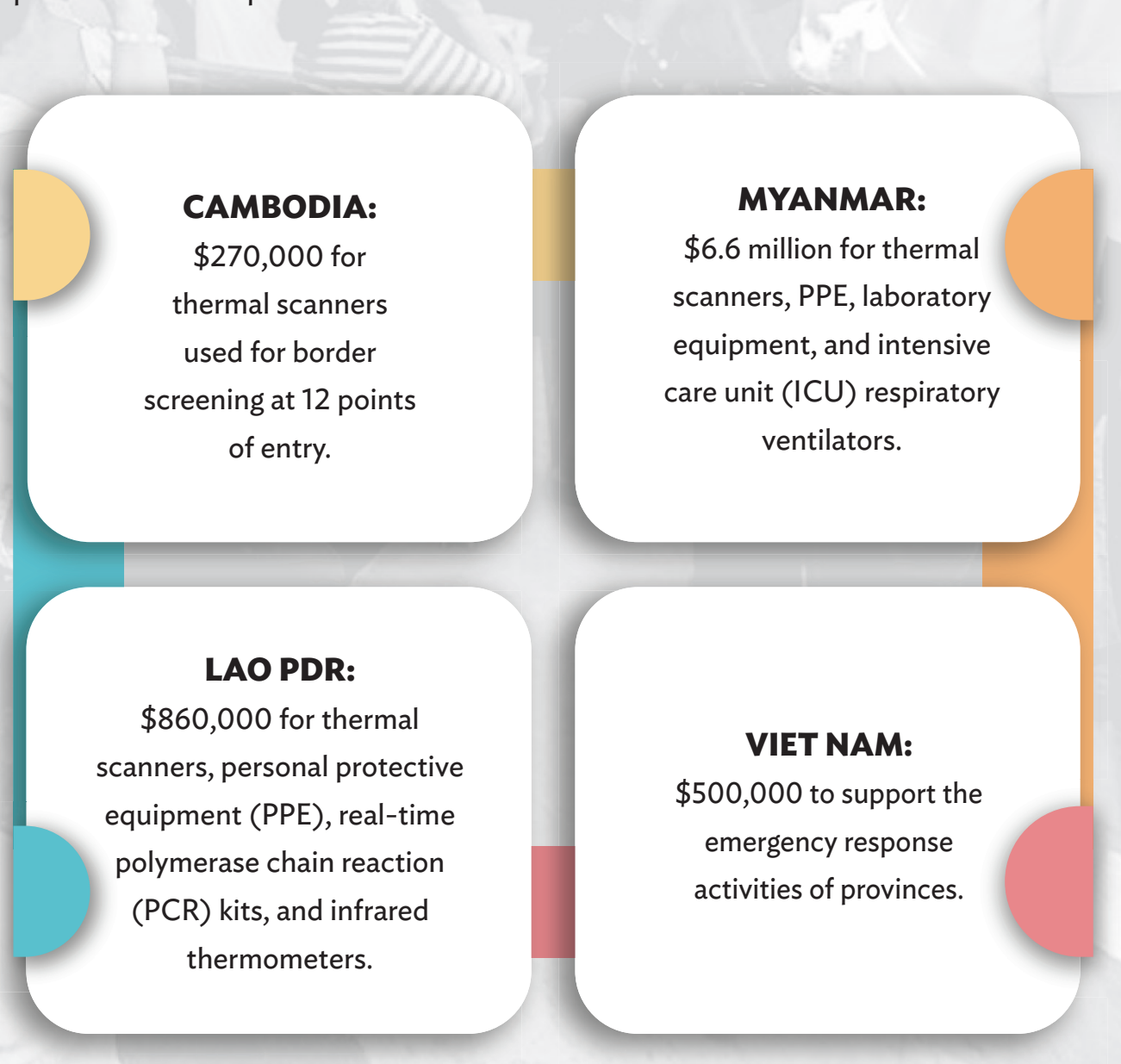




\section{KNOWLEDGE SUPPORT}

Nothing like the current COVID-19 pandemic has been witnessed in modern times. There is therefore no blueprint for an optimal response. The fast-moving and multi-faceted nature of the crisis renders it less amenable to traditional policy analysis. The crisis is extraordinarily challenging for policy makers who are responsible for designing optimal interventions. Accordingly, in Southeast Asia, ADB is providing a suite of knowledge support to help countries contend with this unprecedented challenge.

\section{Policy Advice for COVID-19 Economic Recovery}

On 24 April 2020, ADB approved \$5 million in technical assistance to help countries receiving funding under the CARES Program monitor COVID-19 response package implementation, and to help guide these countries in preparing transformative recovery strategies and action plans through in-depth analysis, private sector and civil society consultations, and high-level policy advice. Through this support, incisive assessments are being undertaken to better understand the pandemic's impact on labor markets, business, value chains, and social protection.

\section{High Level Experts Panel for COVID-19 Recovery in Southeast Asia}

On 9 June ADB convened an interdisciplinary panel of well-known experts in health, economic and social policies, economic development, and finance to dialogue with ministers of finance, national planning, health, and other selected portfolios as well as central bank governors. The dialogue facilitated the sharing of policies and measures that have proven effective in controlling the spread of COVID-19, discussion of innovative ways of supporting economic reopening, and examination of measures that can help guide the formulation of inclusive and equitable recovery strategies and plans. Panel members, listed alphabetically below, are accomplished experts from leading institutions, with current and previous senior-level policy formulation experience.

First High-Level Experts Panel Dialogue on COVID-19 Transition and Recovery in Southeast Asia 9 June 2020

With the participation of: The panel was convened by:

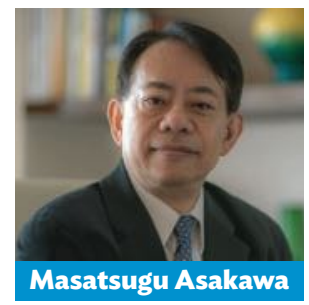

ADB President

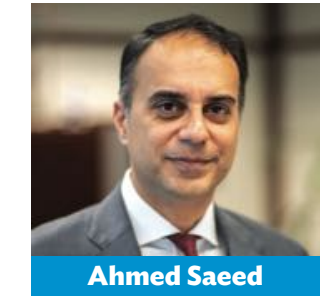

ADB Vice-President
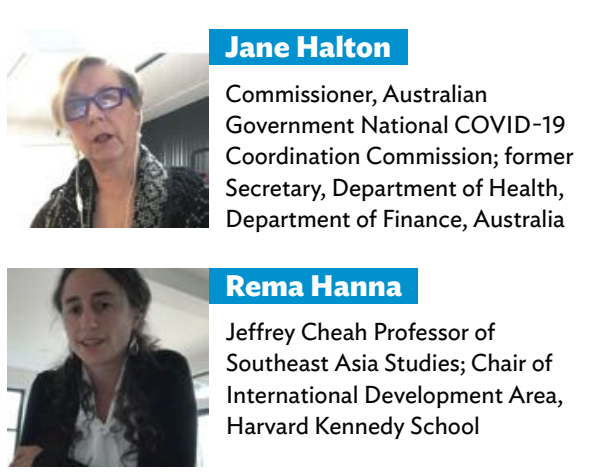

Rema Hanna

Jeffrey Cheah Professor of Southeast Asia Studies; Chair of International Development Area, Harvard Kennedy School

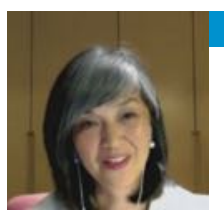

\section{Karen Tay Koh}

Senior Advisor, TVM Health Singapore; former Secretary of Finance, Singapore; former Chief Executive Officer, SingHealth

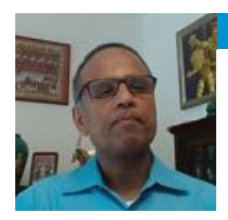

Ramayya Krishnan

Dean, Heinz College of Information Systems and Public Policy, Carnegie Mellon University; President, INFORMS 2019

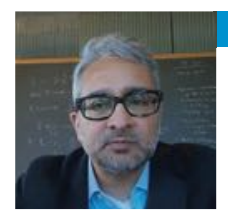

Anup Malani

Professor, Faculty of Law, Faculty of Medicine, University of Chicago

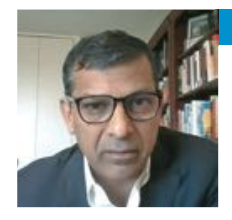

Raghuram Rajan Professor, University of
Chicago; former Governor Reserve Bank of India; former Chief Economist, International Monetary Fund
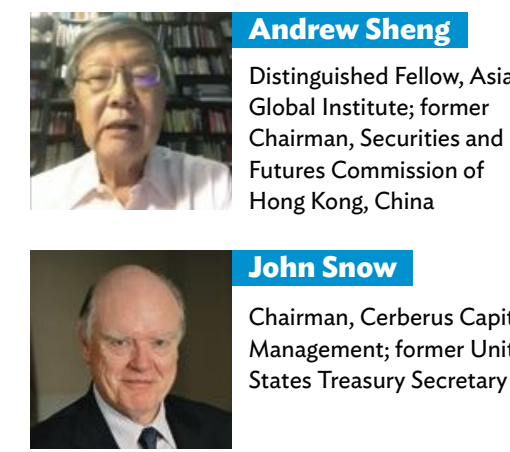

John Snow

Chairman, Cerberus Capital Management; former United States Treasury Secretary

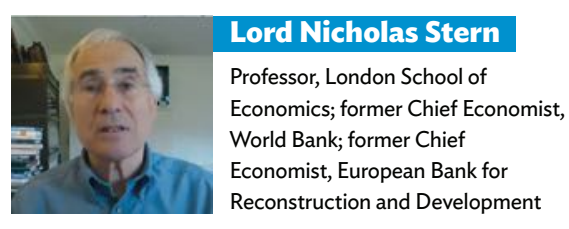


Policy Actions for COVID-19

Economic Recovery (PACER) Dialogues

The PACER Dialogues are an ongoing series of discussions for senior government officials that explore policy measures and actionable initiatives that can help countries "bounce back" from the COVID-19 pandemic and accelerate economic recovery. The dialogues feature expert presentations on a range of issues, and are supported by ADB's "BIG" Program on capacity building involving the Brunei Darussalam - Indonesia- Malaysia Philippines East ASEAN Growth Area (BIMP-EAGA), the Indonesia-Malaysia-Thailand Growth Triangle (IMT-GT), and the GMS. To date the sessions have featured the following topics and experts:

\section{Rapid COVID-19 Country Assessments}

Following the onset of the crisis, ADB's Southeast Asia Regional Department management team, country economists, and economists from ADB's Economic Research and Regional Cooperation Department conducted Country COVID-19 Assessment discussions to explore policy responses to COVID-19. The country economists presented findings on the impact of COVID-19 on their respective countries and analyzed policy actions taken to date. The discussions examined possible gaps in responses, and explored what more can be done on the policy front moving forward.

\begin{tabular}{|c|c|c|}
\hline $\begin{array}{l}\text { 03 JUNE } \\
2020\end{array}$ & $\begin{array}{l}\text { Tackling COVID-19: Economic and Financial Measures of } \\
\text { the Republic of Korea }\end{array}$ & $\begin{array}{l}\text { Kwangchul Ji } \\
\text { Director } \\
\text { Ministry foc Economy and Finance } \\
\text { Republic of Korea }\end{array}$ \\
\hline $\begin{array}{l}17 \text { JUNE } \\
2020\end{array}$ & $\begin{array}{l}\text { Experience and Lessons from New Zealand in Responding to } \\
\text { COVID-19 }\end{array}$ & $\begin{array}{l}\text { Mark Blackmore, Senior Treasury Representative } \\
\text { Mario Di Maio, Principal Advisor, COVID-19 Response } \\
\text { Policy and Strategy } \\
\text { New Zealand Treasury }\end{array}$ \\
\hline $\begin{array}{l}24 \text { JUNE } \\
2020\end{array}$ & $\begin{array}{l}\text { Helping the Tourism Industry Bounce Back from COVID-19: } \\
\text { Broad Policy Responses }\end{array}$ & $\begin{array}{l}\text { Tiffany Misrahi, Vice-President } \\
\text { World Travel and Tourism Council } \\
\text { Mario Hardy, Chief Executive Officer } \\
\text { Pacific Asia Travel Association } \\
\text { Jens Thraenhart, Executive Director } \\
\text { Mekong Tourism Coordinating Office }\end{array}$ \\
\hline $\begin{array}{l}01 \text { JULY } \\
2020\end{array}$ & $\begin{array}{l}\text { Sustainable Social Distancing - Harmonizing Guidelines on } \\
\text { Minimum Health Standards for Post-quarantine COVID-19 }\end{array}$ & $\begin{array}{l}\text { Jeremy Lim } \\
\text { National University of Singapore } \\
\text { Former Ministry of Health official }\end{array}$ \\
\hline $\begin{array}{l}08 \text { JULY } \\
2020\end{array}$ & Bouncing Back Support to SMEs for COVID-19 Recovery & $\begin{array}{l}\text { Paul Vandenberg, Senior Economist } \\
\text { ADB } \\
\text { Foo Ngee Kee, Co-founder and President } \\
\text { Sabah SMEs Association }\end{array}$ \\
\hline $\begin{array}{l}15 \text { JULY } \\
2020\end{array}$ & $\begin{array}{l}\text { Migration and Health: Implications of COVID-19 and } \\
\text { Achieving Universal Health Coverage }\end{array}$ & $\begin{array}{l}\text { Patrick Duigan, Regional Health Migration Advisor } \\
\text { International Organization for Migration } \\
\text { Jadej Thammatcharee, Deputy Secretary General } \\
\text { National Health Security OOffice, Thailand } \\
\text { Heather Canon, Vice President, Capacity Building, ELEVATE }\end{array}$ \\
\hline $\begin{array}{l}22 \text { JULY } \\
2020\end{array}$ & $\begin{array}{l}\text { Harnessing Digital Technologies for Education amid } \\
\text { COVID-19 }\end{array}$ & $\begin{array}{l}\text { Ashish Dhawan, Cofounder, Ashoka University } \\
\text { Chad Pasha, Head of APAC for Global Government Partnerships } \\
\text { Coursera }\end{array}$ \\
\hline $\begin{array}{l}04 \text { AUGUST } \\
2020\end{array}$ & $\begin{array}{l}\text { Post-COVID-19 New Normal: Implications for Startup } \\
\text { Ecosystems }\end{array}$ & $\begin{array}{l}\text { Stephan Kuestner, Head, Global Ecosystem Strategy } \\
\text { Startup Genome, LLC } \\
\text { Seow Hui Lim, Director, Startup Development Division } \\
\text { Enterprise Singapore } \\
\text { Christiaan Kaptein, Partner, Integra Partners }\end{array}$ \\
\hline $\begin{array}{l}12 \text { AUGUST } \\
2020\end{array}$ & Accelerating Digital Financial Services and Infrastructure & $\begin{array}{l}\text { David Lee Kuo Chuen, Professor } \\
\text { Singapore University of Social Sciences } \\
\text { Hae-Rok Ko, General Manager } \\
\text { Center for International Cooperation } \\
\text { Korea Financial Telecommunications and Clearings Institute }\end{array}$ \\
\hline $\begin{array}{l}19 \text { AUGUST } \\
2020\end{array}$ & $\begin{array}{l}\text { Enhancing Readiness for Large-Scale Vaccine Distribution amid } \\
\text { COVID-19 }\end{array}$ & $\begin{array}{l}\text { Farzana Muhib, Asia Team Lead, Vaccine Implementation } \\
\text { Hannah Kettler, Director for Vaccine Financing and Partnership } \\
\text { Huong Minh Vu, Regional Technical Advisor, Vaccine Implementation } \\
\text { PATH } \\
\text { Eduardo P. Banzon, Principal Health Specialist, ADB }\end{array}$ \\
\hline $\begin{array}{l}26 \text { AUGUST } \\
2020\end{array}$ & $\begin{array}{l}\text { Social Protection Interventions as Medium- and Long-Term } \\
\text { Responses amid COVID-19 }\end{array}$ & $\begin{array}{l}\text { Valentina Barca } \\
\text { Edward Archibald } \\
\text { Independent Social Protection Expert }\end{array}$ \\
\hline $\begin{array}{l}23 \text { SEPTEMBER } \\
2020\end{array}$ & $\begin{array}{l}\text { Forecasting COVID-19 and Vaccination Policy: Adaptive } \\
\text { Control for Safer Reopenings and Reduced Infection Rates }\end{array}$ & $\begin{array}{l}\text { Anup Malani, Professor } \\
\text { University of Chicago Law School and University of Chicago Pritzker } \\
\text { School of Medicine }\end{array}$ \\
\hline $\begin{array}{l}24 \text { FEBRUARY } \\
2021\end{array}$ & Managing Safe, Equitable, and Effective COVID-19 Vaccination & Jerome Kim, Director General, International Vaccine Institute \\
\hline
\end{tabular}




\section{NEAR-TERM SOVEREIGN OPERATIONS SUPPORTING COVID-19 RESPONSE}

ADB's current sovereign portfolio in Southeast Asia stands at $\$ 23.3$ billion covering 161 loans and grant projects as of 04 December 2020. Projects originally programmed for 2020 are supporting a continuum of COVID-19 responses to help people and economies in Southeast Asia bounce back from the pandemic. ADB is also working on several policy reform programs in Cambodia, Indonesia, and the Philippines that were planned prior to the pandemic. In Indonesia, policy-based loans (PBL) totaling \$1.1 billion that were programmed for 2020 to promote innovative financial inclusion, and sustainable and inclusive energy access, could be utilized for other critical financing needs related to the COVID-19 crisis. In the Philippines, $\$ 700$ million in PBL programmed to support competitive and inclusive agriculture development and inclusive finance development, and $\$ 500$ million for expansion of the social assistance program, could provide direct support to the country's budget, and be utilized for general economic stimulus. The inclusive agriculture PBL in the Philippines is setting aside $\$ 50$ million to support interest-free loans to small farmers and fisherfolk, and agri- and fishery-based micro and small enterprises (SMEs) affected by the pandemic. ADB is also supporting the rollout of the Philippines Identification System, a first step in developing an integrated platform for identifying social protection program recipients. The government aims to register 5 million low-income heads of households before the end of 2020. Throughout the region ADB is supporting projects addressing water supply and sanitation services, and agriculture value chains. ADB has also reprogrammed $\$ 375$ million in project funds in the agriculture and natural resources sector to adjust for COVID-19 impact, including support for livelihood activities and job creation, as well as training on safety and prevention measures. In the transport sector ADB is making adjustments for COVID-19 by establishing prevention measures in construction sites, strengthening monitoring, and reviewing system designs to minimize risk exposure to infectious diseases.

\section{ADB's COVID-19 Support in Asia and the Pacific $\$ 20$ BILLION}

ADB's overall COVID-19 response package includes $\$ 2.5$ billion in concessional grants and resources.

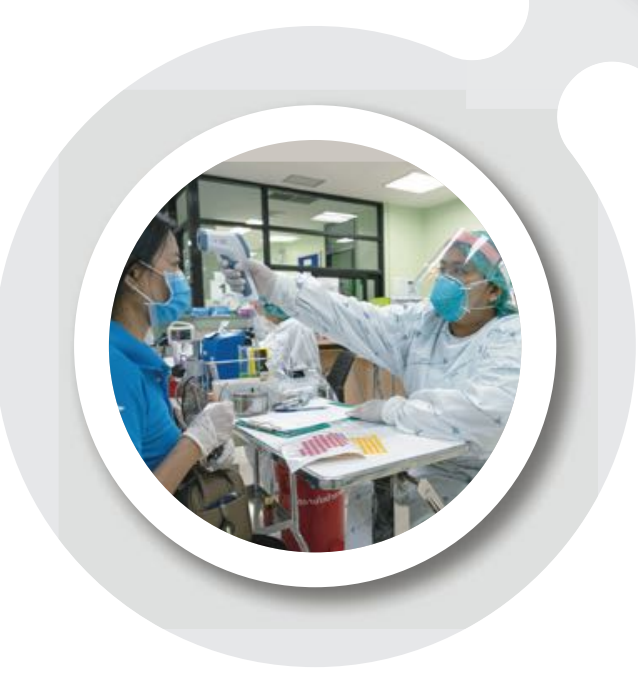

(c) Creative Commons Attribution (c) 2021 Asian Development Bank. Some rights reserved. Published in 2021. ADB recognizes "Korea” as the Republic of Korea. Publication Stock Number: ARM210162-2 DOI: http://dx.doi.org/10.22617/ARM210162-2 This is an updated version of the original flyer released in August 2020.

All photos by $A D B$ unless otherwise indicated. 


\section{ADB and the Private Sector: COVID-19 Response}

ADB teams are working on bringing public and private parties together to forge innovative solutions to address the impact of COVID-19. ADB's Trade and Supply Chain Finance Programs are rapidly channeling crisis response support. Since the onset of the crisis, the Trade Finance Program has supported 1,423 transactions in Viet Nam valued at \$896 million - including $33 \mathrm{med} /$ pharma deals - while the Supply Chain Finance Program has supported 98 medical and pharma transactions in Malaysia valued at \$26 million, and the activation of one PPE supply chain in Indonesia valued at $\$ 10$ million. $A D B$ is also supporting an initiative to map, end-to-end, the entire supply chain for critical pandemic-fighting goods, such as ventilators and N95 masks, to ensure companies encounter no bottlenecks as they ramp up supply. In Indonesia, $A D B$ is exploring opportunities for nonsovereign support to businesses that are critical in ensuring food security, communications, and otherwise responding to the current socio-economic crisis. In the Philippines, ADB has been supporting the public-private "Task Force T3" (test, trace and treat) that supports the government's efforts to swiftly expand testing.

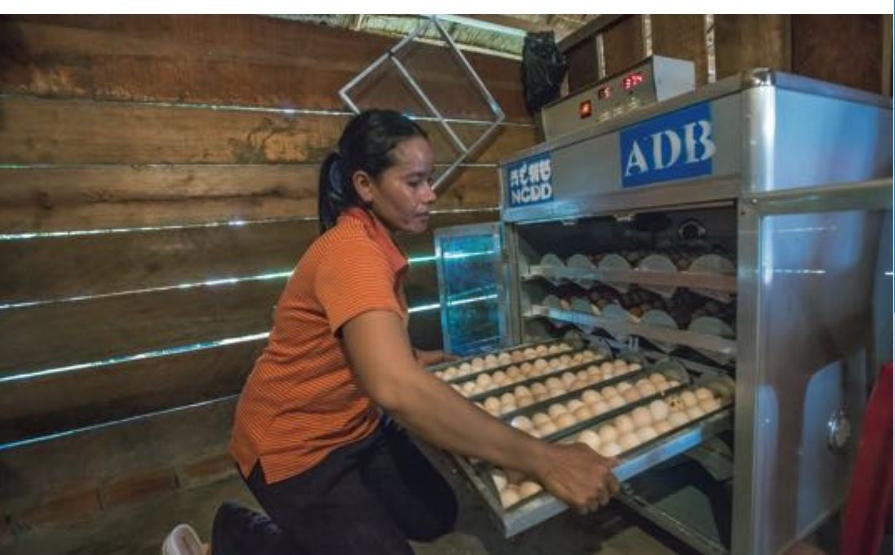

\section{Development Partner Support}

Under the overall lead of respective governments, ADB is closely coordinating its COVID-19 response with key development partners who are also responding with their own packages of support, which involve collaboration and/or cofinancing with ADB. ADB is coordinating with the governments of Cambodia, Indonesia, the Philippines, and Thailand on possible cofinancing of the CARES Program with both multilateral and bilateral development partners. To date, this has resulted in the following commitments: AIIB - \$1.8 billion for Indonesia ( $\$ 750$ million) and the Philippines ( $\$ 1.05$ billion); JICA - about $\$ 1.2$ billion ( $¥ 125$ billion) for Cambodia (\$235 million), Indonesia (\$460 million), and the Philippines ( $\$ 460$ million); Germany's KfW - about $\$ 620$ million ( $€ 550$ million) for Indonesia; and the Government of Australia - about \$1.1 billion (A $\$ 1.5$ billion) for Indonesia. ADB continues to explore cofinancing support for its COVID-19 response programs in close consultation with governments and other potential partners including the Islamic Development Bank, OPEC Fund for International Development, European Investment Bank, European Union as well as philanthropic institutions such as the Bill and Melinda Gates Foundation. ADB is also mobilizing grant and TA resources through direct support, or through ADB-administered trust funds, with contributions from the Nordic Development Fund as well as Australia, France, the People's Republic of China, and the Republic of Korea, among other bilateral partners. To support COVID-19 responses, Japan has also replenished the Japan Fund for Poverty Reduction and the Asia Pacific Disaster Response Fund with $\$ 75$ million each to support COVID-19 responses, enabling support for Timor-Leste. In the Lao PDR, ADB has entered into a collaborative arrangement with the United Nations Children's Fund to facilitate the procurement of APDRF-financed emergency medical supplies and equipment. In Viet Nam, ADB partnered with the Women Entrepreneurs Finance Initiative to provide COVID-19 relief for women-led SMEs.

\section{COVID-19 COFINANCING} $\$ 4.9$ BILLION As of April 2021

\section{One ADB in Action}

COVID-19 is an unprecedented crisis, requiring a multitude of skills and expertise. ADB's Southeast Asia Department coordinates all of the work in the subregion, in close collaboration and in a seamless manner with staff throughout $A D B$ : anticorruption and integrity; communications; economic research and regional cooperation; finance; information technology; legal; private sector operations; procurement and financial management; public-private partnerships; strategy, policy, and partnerships; sustainable development and climate change; and treasury.

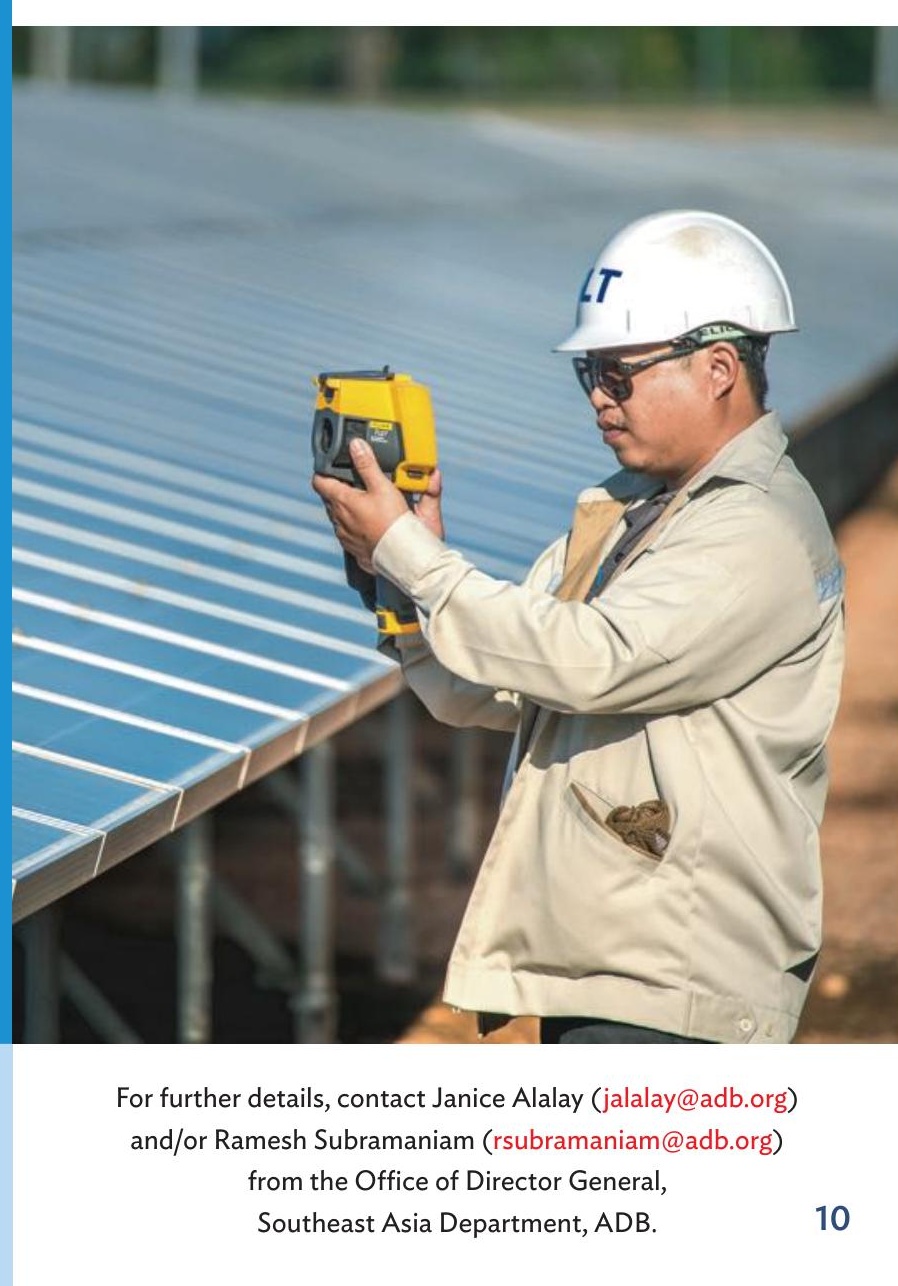

